\title{
The influence of variability in larval dispersal on the dynamics of a marine metapopulation in the eastern Channel
}

\author{
Céline ELLIEN ${ }^{\text {a*}}$, Éric THIEBAUT ${ }^{a}$, Anne-Sophie BARNAY a , Jean-Claude DAUVIN ${ }^{\text {b }}$ \\ Franck GENTIL c, Jean-Claude SALOMON ${ }^{\text {d }}$ \\ a Laboratoire d'océanographie biologique et écologie du plancton marin, CNRS ESA 7076, \\ université Pierre et Marie Curie, Bât. A, Case 6, 4 place Jussieu, 75252 Paris cedex 05, France \\ ${ }^{\mathrm{b}}$ Station marine, CNRS UPRES-A 8013 ELICO, université Lille I, BP 80, 62930 Wimereux, France \\ c Station Biologique, CNRS UPR 9042, université Pierre et Marie Curie, BP 74, \\ 29682 Roscoff cedex, France \\ d IFREMER, Centre de Brest, laboratoire DEL hydrodynamique et sédimentologie, BP 70, \\ 29280 Plouzané, France
}

Revised 2 December 1999; accepted 6 December 1999

\begin{abstract}
In the English Channel, the polychaete Pectinaria koreni forms isolated populations confined in bays and estuaries. To determine the influence of larval dispersal variability on the observed stock fluctuations of the three major Pectinaria koreni populations reported along the French coasts of the eastern Channel, larval dispersal was simulated using a 2D hydrodynamical lagrangian model integrating both the tidal residual and the wind-driven circulation. Year-to-year fluctuations of adult stocks were established from benthic surveys carried out between 1973 and 1998. Larval dispersal patterns vary between populations according to the relative importance of tidal advection and eddy diffusion so that local larval retention is maximal where tidal advection is weak. Wind forcing increases the role of advection on larval transport and modifies greatly the level of retention. Otherwise, wind-induced currents may generate larval colonisation from one population to another one and be involved in reestablishment of depleted populations. Thus, the different local populations of Pectinaria koreni seem to constitute a unique metapopulation, namely a number of subpopulations of adults distributed in a patchy habitat and linked together by their planktonic larval phase. Even if temporal variations of climatic conditions alter larval retention from year to year, larval retention at each site remains generally more intense than larval immigration so that each population can be self-sustained. Year-to-year fluctuations of adult stocks do not seem to be related to larval supply but controlled by post-settlement processes. (C) 2000 Ifremer/CNRS/IRD/Éditions scientifiques et médicales Elsevier SAS
\end{abstract}

\section{larval dispersal / recruitment / modelling / metapopulation / Pectinaria koreni}

Résumé - Influence de la variabilité de la dispersion larvaire sur la dynamique d'une métapopulation marine en Manche. En Manche, l'annélide polychète Pectinaria koreni est une espèce inféodée aux sédiments fins sablo-vaseux ce qui lui confère une distribution insulaire, confinée aux baies et aux estuaires. La présente étude a pour objectif de déterminer l'influence de la variabilité du transport des larves sur la variabilité spatiale et temporelle des trois principales populations adultes de pectinaires réparties le long des côtes françaises de la Manche orientale. La dispersion larvaire a été simulée à l'aide d'un modèle hydrodynamique lagrangien $2 \mathrm{D}$ de circulation des eaux de la Manche intégrant la circulation résiduelle de marée et la circulation induite par le vent.

\footnotetext{
* Correspondence and reprints: celine.ellien@snv.jussieu.fr
} 
Les fluctuations inter-annuelles des stocks adultes ont été établies à partir de différentes campagnes de prélèvements benthiques effectuées entre 1973 et 1998. Les schémas de dispersion larvaire varient entre les populations en fonction de l'importance relative du courant résiduel de marée et de la diffusion turbulente de sorte que la rétention larvaire locale est maximale quand l'advection est faible. Le forçage météorologique accroît le rôle des processus advectifs sur le transport larvaire et modifie fortement le taux de rétention selon la direction et la vitesse du vent. Par ailleurs, les courants induits par le vent peuvent occasionner des flux larvaires entre populations et être impliqués dans le rétablissement de populations perturbées. Ainsi, en Manche orientale, les différentes populations locales de Pectinaria koreni ne semblent constituer qu'une seule unité fonctionnelle structurée en métapopulation, c'est-à-dire un ensemble de sous-populations adultes distribuées dans un environnement fragmenté et reliées entre elles par leurs stades larvaires planctoniques. Bien que les variations climatiques inter-annuelles affectent la rétention larvaire d'une année sur l'autre, la rétention larvaire à chaque site demeure généralement supérieure aux apports allochtones de sorte que chaque population peut s'auto-alimenter. Les fluctuations inter-annuelles des populations adultes ne paraissent pas liées aux apports larvaires mais être contrôlées par les mécanismes affectant la dynamique des jeunes recrues benthiques. (C) 2000 Ifremer/CNRS/IRD/Éditions scientifiques et médicales Elsevier SAS

\section{dispersion larvaire / recrutement / modélisation / métapopulation / Pectinaria koreni}

\section{INTRODUCTION}

In shallow marine waters, most benthic invertebrates reproduce by way of a planktonic stage which may be largely dispersed in the water column before settling to the substrate and undergoing metamorphosis. This dispersive larval phase could be a very important stage in explaining population dynamics of such species. Thus patterns of local adult population distribution and abundance are at least partly determined by the supply of recruits, itself linked to larval dispersal schemes $[11,45]$. Because of the poor swimming abilities of larvae, larval dispersal depends mainly on mesoscale spatial hydrodynamic features (e.g. tidal residual currents, wind-driven currents, density currents, fronts and gyres) [39, 40]. Hydrodynamic conditions, according to their intensity and direction, either retain larvae in the vicinity of adult populations, which enables a local recruitment, or on the contrary transport the dispersive stages away from their source population. The export may be advantageous for the population if juveniles are able to diversify their resources of food and space by colonizing other substrates and thus lessen competition with dense populations of adults [45]; in contrast, it may be disadvantageous for the population if it causes the loss of a larval cohort [39]. On the other hand, for shallow-water marine ecosystems, it has been shown that physical perturbations and biological interactions such as competition and predation, frequently lead to the extinction of local populations in many habitats. Rapid recolonisation by the larval phase allows the survival and persistence of spatially isolated benthic populations $[3,18]$.

In the English Channel, intense tidal currents control the distribution of superficial sediments, so that pebbles and gravels dominate in the open sea while sands and muds are confined in bays and estuaries where currents are weaker [27]. As the distribution of benthic communities is closely related to these hydrodynamic and sedimentary gradients [7], the patchy distribution of fine sediment species provides an ideal environment to determine the role of biological and physical processes involved in larval dispersal and recruitment. Within the framework of the French program, Programme National sur le Déterminisme du Recrutement, the tubicolous polychaete Pectinaria koreni, which is one of the dominant species of the Abra alba muddy fine sand community in the eastern Channel $[6,15,16,41]$, has been retained as a target species for our studies.

Pectinaria koreni is an univoltine species living 1518 months with a main breeding period occurring between April and July [9, 21]. Since 1986, in the eastern Bay of Seine, intensive field studies have identified the main processes involved in Pectinaria 
koreni larval dispersal: larval ontogenic vertical migration, the Seine River plume front, tidal residual currents and wind-driven currents. It is to be noted that the wind is a crucial factor explaining the Pectinaria koreni larval dispersal variability [23, 24, 42].

Given the difficulties met by ecologists in tracking larvae in the field [13], one available alternative is the use of mathematical models which provide a quantitative method of applying physical oceanographic information to larval dispersal $[14,20,44]$. These models give a synoptic view of larval distribution for a large range of geographic, hydrodynamic and climatic conditions at different spatial and temporal scales. Moreover, they can determine the relative influence of the various components of hydrodynamic circulation and specific biological characteristics on larval dispersal.

For the English Channel, a lagrangian two-dimensional (2D) numerical model of water circulation has been elaborated by Salomon [35, 36]. The model, first elaborated to study the hydrodynamics of the English Channel has been used to simulate water mass exchange between the English Channel and the North Sea [37] and the transport of dissolved substances [4, 17]. In the eastern Bay of Seine, its application to the transport of Pectinaria koreni larvae showed a good agreement between field observations and simulated results in terms of larval dispersal schemes and highlighted the determinant role of wind-induced currents [10].

The objective of the present study is to determine the role of the larval phase at a regional scale on the functional structure of Pectinaria koreni populations, and the effects of larval dispersal variability on the recruitment and the dynamics of benthic adult populations. The three Pectinaria koreni populations distributed along the French coasts of the eastern English Channel (i.e. the Bay of Veys, the eastern Bay of Seine and along the coast between Dieppe and Boulogne/mer) have been considered within this study. The numerical model of the English Channel is used to investigate influences of the location of spawning sites, tidal residual currents and the variability in hydrodynamic circulation induced by wind on larval dispersal. Observations on adult stock variability are presented in this paper, linked to the results of model simulations.

\section{MATERIAL AND METHODS}

\subsection{Study areas and benthic sampling}

Along the French coasts of the eastern English Channel, three populations of Pectinaria koreni located within the Abra alba muddy fine sand community are reported in two semi-enclosed bays, the eastern Bay of Seine and the Bay of Veys, and along the coast between Dieppe and Boulogne/mer (figure 1) $[5,6$, 16]. In the two former sites, the populations cover restricted areas of about 400 and $100 \mathrm{~km}^{2}$ respectively. In the latter site (hereafter referred to as "Picarde Bay"), the population extends over a thin band of muddy sand of about $200 \mathrm{~km}^{2}$ (100 km long and $1-4 \mathrm{~km}$ wide).

At the three sites the distribution and abundance of Pectinaria koreni were assessed from different surveys carried out between 1973 and 1998 for community studies. The main characteristics of the methodology used during the surveys are given in table I. During the 1970s, a semi-quantitative sampling was performed using a Rallier du Baty dredge. A volume of $30 \mathrm{~L}$ of sediment was sieved through a $2-\mathrm{mm}$ circular mesh from each dredge sample and live organisms were sorted and counted on board. These data were kindly provided by Dr Louis Cabioch (Station Biologique de Roscoff). During the 1980s and 1990s, samples (i.e. two replicates per station) were collected using a $0.25 \mathrm{~m}^{2}$ Hamon grab. They were then sieved as previously and preserved in $10 \%$ buffered formalin prior to sorting and counting in the laboratory.

Due to the heterogeneity in the sampling device, the sampling period (i.e. before or after the recruitment) and the number of sampled stations among sites and years, the year-to-year variability in the Pectinaria koreni abundance and distribution should be analyzed with caution. Only changes of a large magnitude could be determined.

\subsection{Numerical model}

The advection-dispersion numerical model used for this study simulates transport and mixing of dissolved substances and planktonic particles on time-scales 
ranging from days to years, under the influence of a hydrodynamism dominated by tide and wind forces, by solving the following equation:

$\frac{\partial \mathrm{C}}{\partial \mathrm{t}}+\mathrm{u} \frac{\partial \mathrm{C}}{\partial \mathrm{x}}+\mathrm{v} \frac{\partial \mathrm{C}}{\partial \mathrm{y}}-\mathrm{K}\left(\frac{\partial^{2} \mathrm{C}}{\partial \mathrm{x}^{2}}+\frac{\partial^{2} \mathrm{C}}{\partial \mathrm{y}^{2}}\right)-\mathrm{mC}=0$ with:

$\mathrm{u}$, velocity along $\mathrm{x}$ axis

$\mathrm{v}$, velocity along y axis

$\mathrm{m}$, larval mortality coefficient

$\mathrm{C}$, larval concentration

$\mathrm{K}$, tensor of turbulent diffusion.

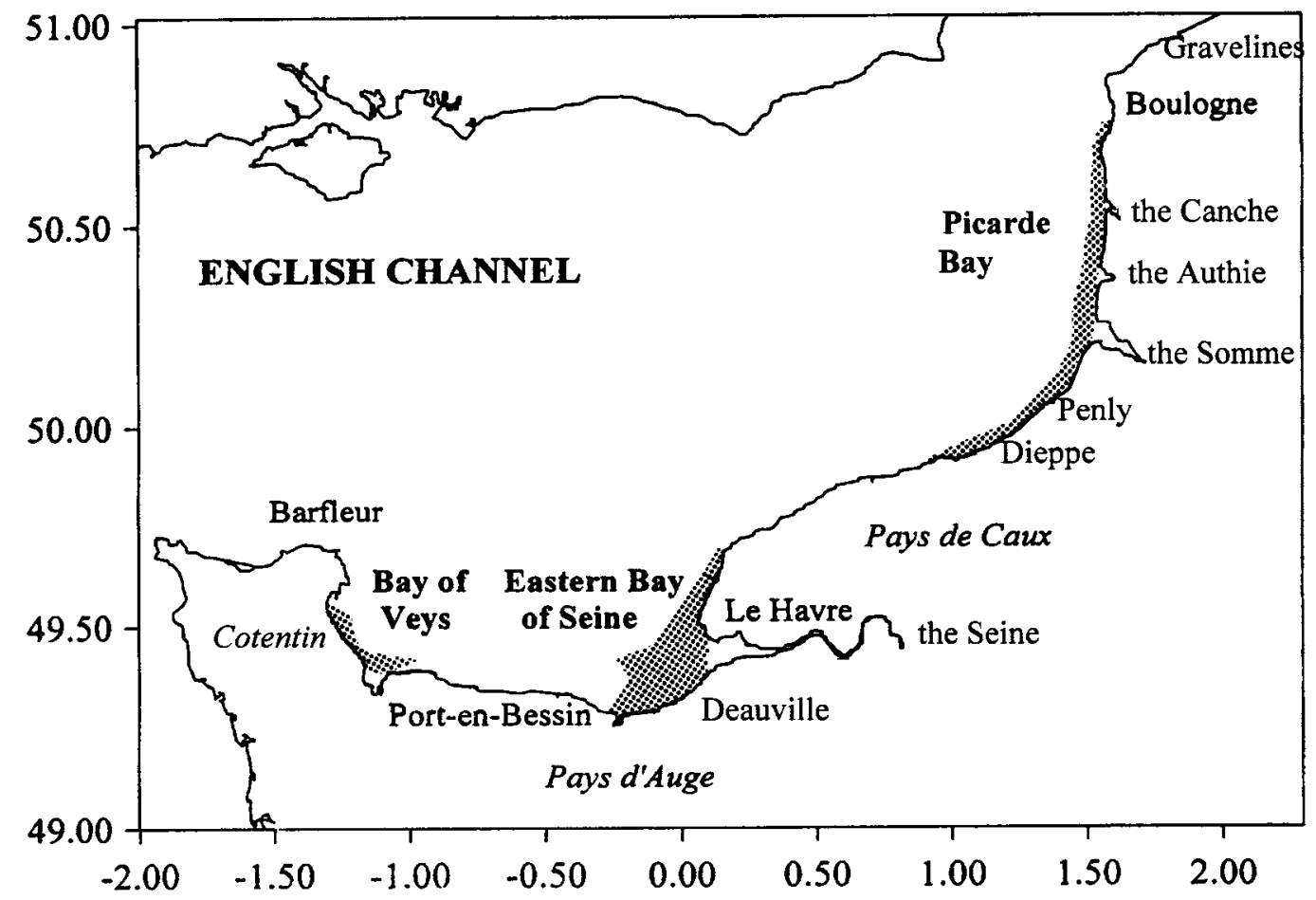

Figure 1. Location of study areas and distribution of the Abra alba muddy-fine sand community along the French coasts of the eastern English Channel $[5,6,16]$ which is indicated by dotted areas.

Table I. Main characteristics of sampling surveys of Pectinaria koreni populations in the eastern English Channel.

\begin{tabular}{llcl}
\hline Site & period & Stations & device \\
\hline Eastern Bay of Seine & February 1986 & 40 & Hamon grab \\
& February 1987 & 51 & Hamon grab \\
& February 1988 & 67 & Hamon grab \\
& March 1991 & Hamon grab \\
Bay of Veys & March 1996 & 64 & Hamon grab \\
& March 1973 & 79 & Rallier du Baty dredge \\
& September 1979 & 54 & Hamon grab \\
March 1991 & Harch 1997 & 5 & Hamon grab \\
& October 1997 & 12 & Hamon grab \\
& July 1973 & 64 & Rallier du Baty dredge \\
& July-September 1974 & 57 & Rallier du Baty dredge \\
& August 1975 & 48 & Rallier du Baty dredge \\
\hline
\end{tabular}


Table II. Coordinates of larval release for the three major populations of Pectinaria koreni along the French coasts of the eastern English Channel.

\begin{tabular}{lll}
\hline & Longitude & Latitude \\
\hline Eastern Bay of Seine & $0^{\circ} 05^{\prime} 43^{\prime \prime}, \mathrm{W}$ & $49^{\circ} 25^{\prime} 16^{\prime \prime} \mathrm{N}$ \\
Bay of Veys & $1^{\circ} 07^{\prime} 38^{\prime \prime} \mathrm{W}$ & $49^{\circ} 25^{\prime} 16^{\prime \prime} \mathrm{N}$ \\
$\begin{array}{l}\text { Picarde Bay, off Penly } \\
\text { Picarde Bay, off the Bay of }\end{array}$ & $1^{\circ} 11^{\prime} 40^{\prime \prime} \mathrm{E}$ & $50^{\circ} 00^{\prime} 52^{\prime}, \mathrm{N}$ \\
$\quad 1^{\circ} 27^{\prime} 08^{\prime \prime} \mathrm{E}$ & $50^{\circ} 27^{\prime} 08^{\prime \prime} \mathrm{N}$ \\
$\begin{array}{l}\text { Somme } \\
\quad \text { Picarde Bay, off the Canche }\end{array}$ & $1^{\circ} 27^{\prime} 08^{\prime \prime} \mathrm{E}$ & $50^{\circ} 30^{\prime} 33^{\prime \prime} \mathrm{N}$ \\
$\quad$ & & \\
\hline
\end{tabular}

The advection-dispersion model was driven by predicted currents and diffusion from an hydrodynamical model of the English Channel, limits of which are $48^{\circ} 18^{\prime} \mathrm{N}$ and $51^{\circ} 20^{\prime} \mathrm{N}$ in latitude, $6^{\circ} 28^{\circ} \mathrm{W}$ and $3^{\circ}$ $00^{\prime} \mathrm{E}$ in longitude. Its mesh size which has to be much smaller than tidal excursions is fixed to one nautical mile, thus forming a grid of $367 \times 184$ cells [35]. The hydrodynamical model is a submodel inserted inside a more global one of the whole North European shelf which provides boundary conditions $[35,36]$.

The hydrodynamical model computes instantaneous and residual velocities and trajectories for different tide and wind conditions through the 'barycentric technique' $[34,36]$. Thus, for each tide/wind combination, this technique provides a single residual velocity field which sums all components of the current: the Eulerian and Stokes residuals and Lagrangian drift. The residual velocity field enables to solve the advection-diffusion equation using a numerical conservative method [38].

The calculations within the hydrodynamical model use a semi-diurnal tide, called D2 which is a combination of the main tidal components on the northwest European continental shelf, M2 and S2. The model assumes a uniform wind stress over the whole area. Wind stress is evaluated as follows:

$\tau=\rho_{\mathrm{a}} \mathrm{C}_{\mathrm{W}}|\mathrm{W}| \overrightarrow{\mathrm{W}}$

with :

$\tau$, wind stress

$\rho_{\mathrm{a}}$, mass per unit volume of air

$\mathrm{C}_{\mathrm{w}}$, drag coefficient $=0.0015 \mathrm{~kg} \mathrm{~m}^{-3}$

$\overrightarrow{\mathrm{W}}$, wind vector.
The diffusion coefficient (K) was calculated using Elder's law linking this coefficient to current velocity $(\mathrm{U})$ and water depth $(\mathrm{H})$, considering the proportionality coefficient $(\beta)$ as a function of the time scale:

$\mathrm{K}=\beta \mathrm{UH}$

According to [36], $\beta$ would be close to 0.3 for periods of about half a week.

\subsection{Presentation of simulations}

The locations of larval release in the model correspond to the major observed Pectinaria koreni populations along the French coasts of the eastern English Channel. The larval release areas are located on ten square nautical miles around the coordinates given on table II. A single release area has been considered for the eastern Bay of Seine and for the Bay of Veys, while three areas have been chosen for the Picarde Bay due to the latitudinal extend of the muddy fine sand community. Three release areas in this latter site seem thus more representative of the population distribution.

The quantity of larvae released in the different studied sites is equal to $6.89 \times 10^{14}$ larvae, i.e. $10^{7}$ larvae per square metre. According to the effective fecundity of females, which ranged between 20000 and 1200000 ovocytes per female [1], and the sex-ratio equal to 1 [9], this quantity of larvae represents approximatively an adult population density of 17 to 50 ind. $\cdot \mathrm{m}^{-2}$. Such a density is comparable with averaged adult densities of Pectinaria koreni in the eastern Bay of Seine which vary between 32 and 85 ind. $\mathrm{m}^{-2}$ [41].

Larval dispersal was simulated for a period of 15 days which corresponds to the period of larval development estimated to be about two weeks from in situ observations [25]. As this study is mainly concerned with the scheme of larval dispersal and the relative differences in the number of larvae settled on favourable or unfavourable substrate for their benthic development, the mortality term was set to zero.

All the simulations were made considering an average tide and a constant wind of speeds ranging from 0 to $15 \mathrm{~m} \cdot \mathrm{s}^{-1}$. Two wind directions which correspond to the dominant winds in the studied area during the Pectinaria koreni spawning period were tested: NE 
(direction $45^{\circ}$ ) and $\mathrm{SW}$ (direction $225^{\circ}$ ). Wind measurements in the eastern Bay of Seine during AprilJune period for 1962 to 1997 show that N-NE wind (direction varying between $340^{\circ}$ and $60^{\circ}$ ) blew $36.5 \%$ of the time and $\mathrm{W}-\mathrm{SW}$ wind (direction varying between $200^{\circ}$ and $280^{\circ}$ ) was reported for $30.5 \%$ of the time (Meteo-France data).

With the aim of quantifying the proportion of Pectinaria koreni larvae settling on favourable substrates at the end of the dispersive phase, the substrate of the English Channel was translated into a $0 / 1$ matrix ( 0 : unsuitable substrate; 1 : suitable substrate). The favourable areas for the development of Pectinaria koreni juveniles have been determined from the distribution charts of muddy-fine sand communities along the French coasts of the eastern English Channel [5, $6,16]$. Each cell of the model grid has been coded either by 1 or 0 if it represents a cell where larvae are able or not to survive. So the number of larvae settling on a favourable substrate corresponds to the sum of the larvae settling on each cell multiplied by 0 or 1 .

\section{RESULTS}

\subsection{Interannual variability of benthic adult populations}

The year-to-year changes in Pectinaria koreni adult densities and spatial distribution fluctuated strongly between sites.

In the eastern Bay of Seine, Pectinaria koreni population exhibited weak interannual changes. The species was present at 55 to $72 \%$ of the stations sampled between 1986 and 1996 within the muddy-fine sand community (figure 2). Maximal density values differed between years by less than one order of magnitude. Thus, they reached 168 ind. $0.5 \mathrm{~m}^{-2}$ in 1986 , 712 ind. $0.5 \mathrm{~m}^{-2}$ in 1987,333 ind. $\cdot 0.5 \mathrm{~m}^{-2}$ in 1988 , 211 ind. $0.5 \mathrm{~m}^{-2}$ in 1991 and 165 ind. $0.5 \mathrm{~m}^{-2}$ in 1996. Moreover, patches of high abundance were commonly reported off the Seine estuary and off Deauville.

In the Bay of Veys, the occurrence and abundance of Pectinaria koreni varied greatly between years at different temporal scales as illustrated by data collected from 1973 to 1997 (figure 3). In 1973, Pectinaria koreni was observed in only a few sampled stations with abundance $<10$ ind. $(30 \mathrm{~L})^{-1}$. In the same way, Pectinaria koreni densities did not exceed 10 ind. $0.5 \mathrm{~m}^{-2}$ in 1979 and 1991. Conversely, in March 1997, the species occurred in $57 \%$ of sampled stations with densities ranging between 1 and 329 ind. $0.5 \mathrm{~m}^{-2}$; these organisms resulted from a high recruitment in spring-summer 1996. On the other hand, in October 1997, the recruits which are the sole part of the population mapped on figure $3 e$, exhibited densities ranging between 1 and 33 ind. $\cdot 0.5 \mathrm{~m}^{-2}$.

The data obtained in the Picarde Bay between 1973 and 1998 showed large interannual fluctuations of Pectinaria koreni distribution and densities (figure 4). In 1974, Pectinaria koreni was located in a few stations between Dieppe and the south of the Bay of Somme and off the Canche estuary. Densities remained low (i.e. $<10$ ind. $\left.(30 \mathrm{~L})^{-1}\right)$ except at one station where they reached 400 ind. $(30 \mathrm{~L})^{-1}$. By contrast, in 1975, the species was observed in the former area in most of the sampled stations at densities 10 ind. $(30 \mathrm{~L})^{-1}$. In 1998, it was only collected occasionally off the Bay of Somme and off Dieppe at densities ranging between 1 and 7 ind. $0.5 \mathrm{~m}^{-2}$.

\subsection{Simulated larval dispersal}

\subsubsection{Larval release from the eastern Bay of Seine}

Without wind, the larval cohort spreads to the west along the coasts of Pays d'Auge and to the northwest along the coasts of Pays de Caux (figure 5). However, due to diffusion, the cohort dispersal is relatively isotropic. Maximal larval abundances ( $>10000$ larvae $\mathrm{m}^{-3}$ ) are noticed off the Seine estuary where the presence of favourable substrates for benthic development would favour autorecruitment: $58.05 \%$ of the larval cohort are retained on areas where adults are present after 15 days of dispersal (table III).

Wind-induced currents have a strong effect on the dispersal patterns, modifying the shape of the larval panache and the level of retention on the suitable substrates of the eastern Bay of Seine (figure 5; table $I I I)$. In the case of a SW wind, the larval cohort spreads northeastwards, whereas it is transported westwards for a NE wind. The larval maximal abundance patches are also displaced under wind effects. 

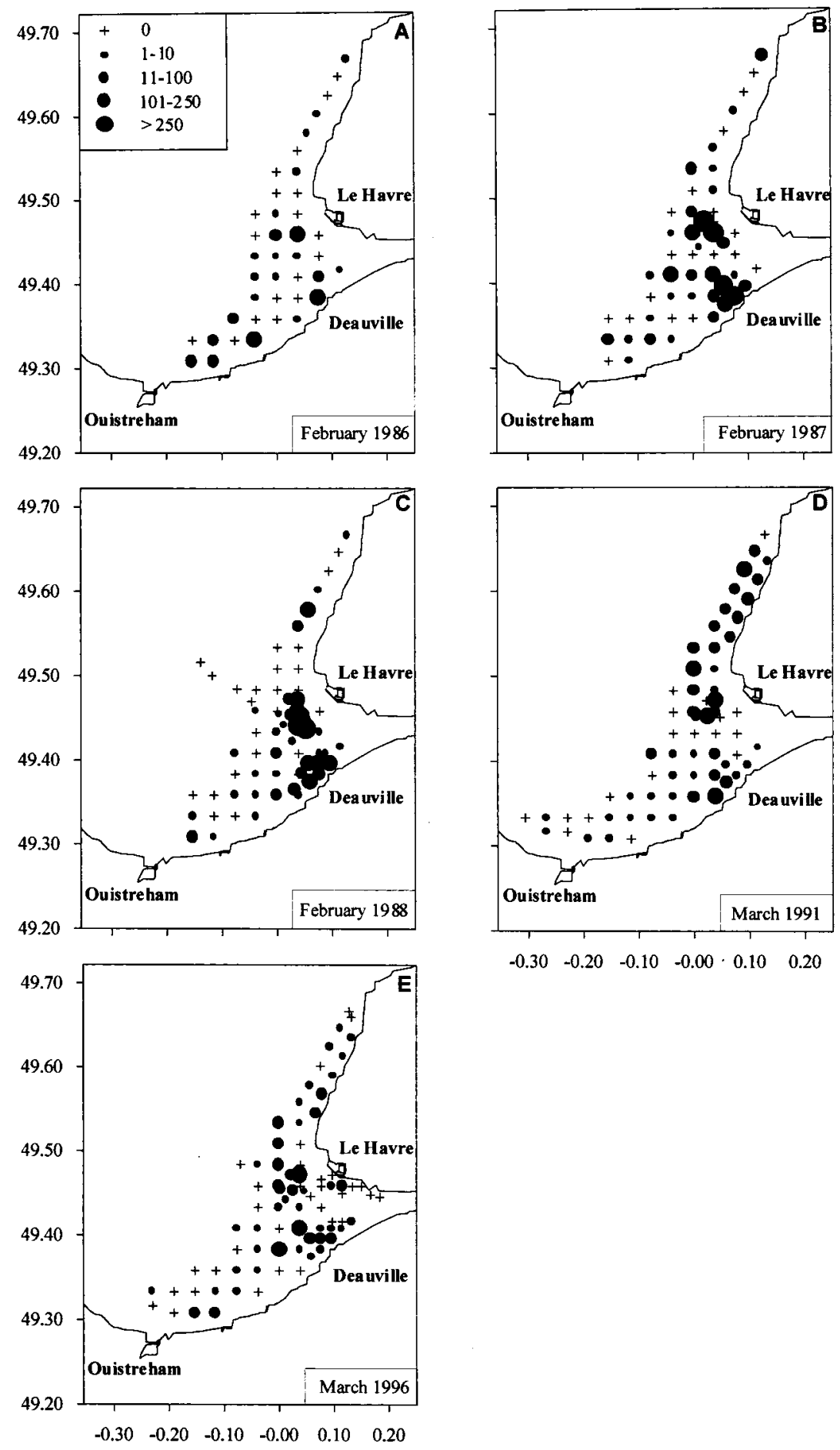

Figure 2. Distribution and densities of Pectinaria koreni in the eastern Bay of Seine. (A) February 1986. (B) February 1987. (C) February 1988. (D) March 1991. (E) March 1996. Densities are expressed in ind. $\left(0.5 \mathrm{~m}^{2}\right)^{-1}$. 

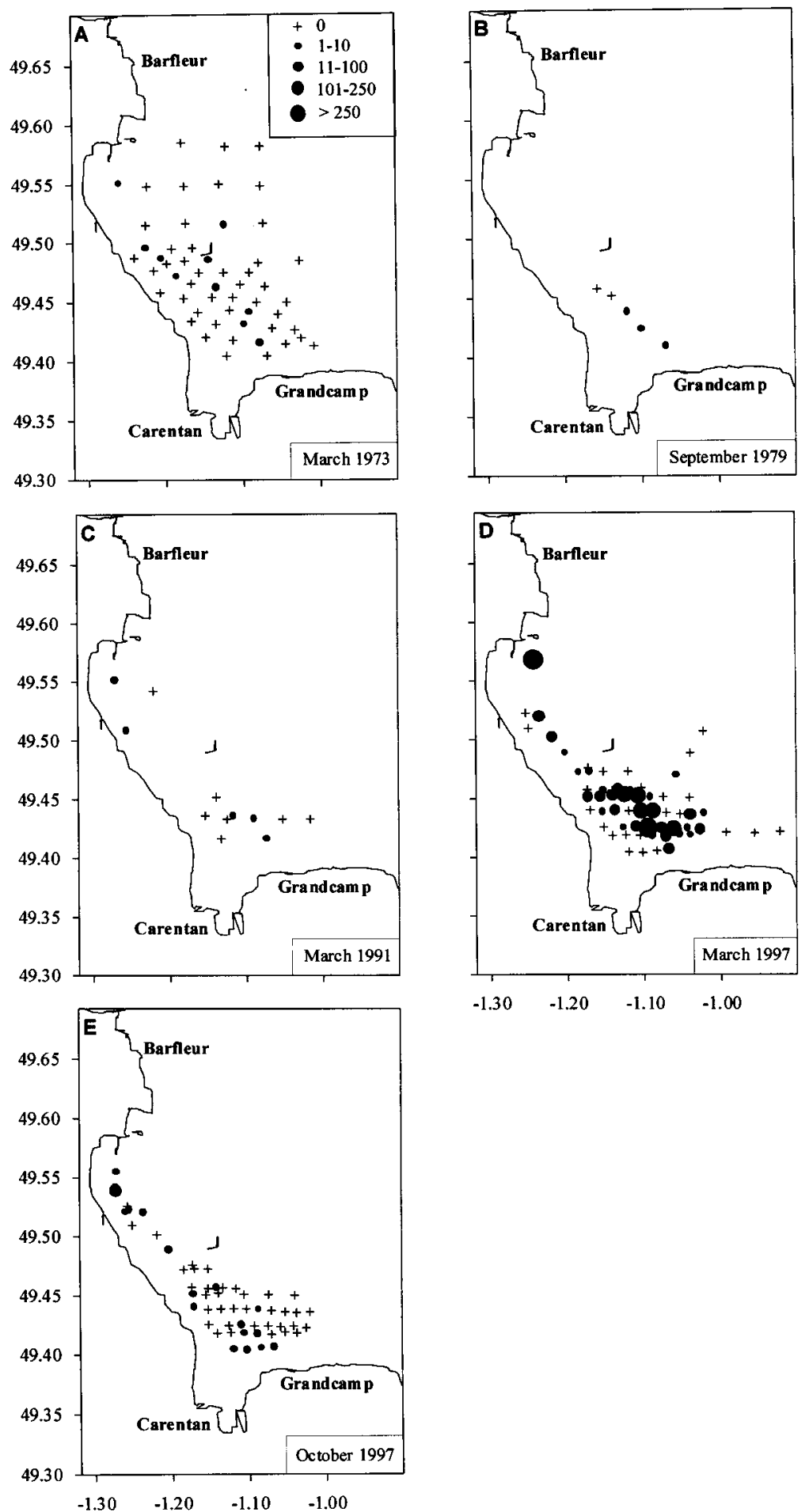

Figure 3. Distribution and densities of Pectinaria koreni in the Bay of Veys. (A) March 1973. (B) September 1979. (C) March 1991. (D) March 1997. (E) October 1997. Densities are expressed in ind. $(30 \mathrm{~L})^{-1}$ of sediment in 1973 and in ind. $\left(0.5 \mathrm{~m}^{2}\right)^{-1}$ in 1979,1991 and 1997. 
Table III. Influence of larval release sites and wind forcing on larval retention and colonisation. Retention is the percentage of released larvae that settled on suitable substrates of the local adult population. Colonisation is the percentage of released larvae that settled on suitable substrates of a distant population.

\begin{tabular}{|c|c|c|c|c|c|c|c|c|c|c|c|c|}
\hline \multirow{2}{*}{$\begin{array}{l}\text { Wind direction } \\
\text { Wind speed } \\
\left(\mathrm{m} \cdot \mathrm{s}^{-1}\right)\end{array}$} & \multicolumn{6}{|c|}{ NE Wind } & \multicolumn{6}{|c|}{ SW wind } \\
\hline & 0 & 3 & 6 & 9 & 12 & 15 & 0 & 3 & 6 & 9 & 12 & 15 \\
\hline \multicolumn{13}{|c|}{ Eastern Bay of Seine } \\
\hline Retention & 58.05 & 54.14 & 21.77 & 1.02 & 0.01 & $2.10^{-3}$ & 58.05 & 53.56 & 31.35 & 13.31 & 1.23 & 0.34 \\
\hline Colonisation & 0 & 0 & 0 & $1.10^{-3}$ & 1.18 & 7.58 & 0 & 0 & 0 & 0 & $5.10^{-5}$ & 3.00 \\
\hline \multicolumn{13}{|l|}{ Bay of Veys } \\
\hline Retention & 3.70 & 3.54 & 3.13 & 2.51 & 1.64 & 1.24 & 3.70 & 3.72 & 3.58 & 3.28 & 3.54 & 6.69 \\
\hline Colonisation & 0 & 0 & 0 & 0 & 0 & $2.10^{-4}$ & 0 & 0 & 0 & 0 & 0 & $9.10^{-3}$ \\
\hline \multicolumn{13}{|c|}{ Picarde estuaries - Penly } \\
\hline Retention & 23.22 & 21.04 & 21.48 & 3.74 & 0.32 & 0.04 & 23.22 & 27.28 & 36.13 & 32.36 & 18.28 & 8.00 \\
\hline Colonisation & 0 & 0 & 0 & $4.10^{-5}$ & 1.80 & 39.19 & 0 & 0 & 0 & $1.10^{-5}$ & 5.31 & 2.86 \\
\hline \multicolumn{13}{|c|}{ Picarde estuaries - Somme } \\
\hline Retention & 40.78 & 40.20 & 37.01 & 22.93 & 8.50 & 1.73 & 40.78 & 40.35 & 37.30 & 25.11 & 13.71 & 6.37 \\
\hline Colonisation & 0 & 0 & 0 & 0 & 0 & 7.27 & 0 & 0 & 0 & 1.29 & 3.69 & 2.50 \\
\hline \multicolumn{13}{|c|}{ Picarde estuaries - Canche } \\
\hline Retention & 3.48 & 4.19 & 16.84 & 24.82 & 10.54 & 1.05 & 3.48 & 3.89 & 1.90 & 0.64 & 0.22 & 0.06 \\
\hline Colonisation & 0 & 0 & 0 & 0 & 0 & 0.01 & 0 & $1.10^{-3}$ & 2.15 & 2.80 & 0.33 & 0.08 \\
\hline
\end{tabular}

For a SW wind, high larval densities (hereafter referred to as 1000 larvae $\cdot \mathrm{m}^{-3}$ ) remain off the Seine estuary, even if the maximal densities (i.e. $>10000$ larvae $\cdot \mathrm{m}^{-3}$ ) are reported along the coasts of Pays de Caux. However, for a NE wind, high larval densities are flushed toward the coasts of Cotentin. Thus, for a $\mathrm{NE}$ wind of $12 \mathrm{~m} \cdot \mathrm{s}^{-1}$, only low larval densities ( < 11 larvae $\cdot \mathrm{m}^{-3}$ ) remains off the Seine estuary. Consequently, the percentage of retained larvae which succeed in settling decreased sharply in response to wind speed increase, and even more strongly for NE winds than for SW winds. About $31.35 \%$ of the larval stock remains on the favourable substrates of the eastern Bay of Seine for a SW wind of $6 \mathrm{~m} \cdot \mathrm{s}^{-1}$, and $1.23 \%$ for a SW wind of $12 \mathrm{~m} \cdot \mathrm{s}^{-1}$. For a NE wind, the proportions of larvae remaining on these suitable substrates are $21.77 \%$ for a NE wind of $6 \mathrm{~m} \cdot \mathrm{s}^{-1}$ and $0.01 \%$ for a NE wind of $12 \mathrm{~m} \cdot \mathrm{s}^{-1}$.

Larvae released from the eastern Bay of Seine are able to colonise other favourable substrates off the French coasts of the eastern English Channel under particular wind conditions (table III). Thus some of them can be transported to the suitable substrates located along the coasts of Pays de Caux, off Dieppe, for a SW wind $\geq 12 \mathrm{~m} \cdot \mathrm{s}^{-1}$ during 15 consecutive days. The percentage of larvae settling on these substrates is equal to $5 \times 10^{-5} \%$ (for a SW wind of 12 $\mathrm{m} \cdot \mathrm{s}^{-1}$ ) and $3.00 \%$ (for a SW wind of $15 \mathrm{~m} \cdot \mathrm{s}^{-1}$ ). In the same way, the larval panache can reach the favourable substrates of the Bay of Veys for a NE wind blowing at a speed $\geq 9 \mathrm{~m} \cdot \mathrm{s}^{-1}$ during 15 consecutive days: 0.001 to $7.58 \%$ of released larvae can settle on the muddy fine sand of the Bay of Veys.

\subsubsection{Larval release from the Bay of Veys}

Without wind, the larval cohort is carried northwards along the coasts of Cotentin due to advection and reaches a gyre off Barfleur where larvae are trapped (figure 6). Maximum larval densities ( > 10000 larvae $\mathrm{m}^{-3}$ ) are confined along the coasts from the Bay of Veys to Barfleur, even if a part of the cohort is trapped inside the gyre. At the end of the dispersive 
phase, $3.70 \%$ of the larval cohort remain on adult areas (table III).

The influence of the wind on larval dispersal varies according to its direction and intensity (figure 6; table $I I I)$. For a SW wind, the eddy structure off Barfleur is weakly modified, even for a strong SW wind. As an example, for a SW wind of $12 \mathrm{~m} \cdot \mathrm{s}^{-1}$, the gyre is displaced southwards and the spreading out of the larval panache increases eastwards. For wind speed $\leq 12 \mathrm{~m} \cdot \mathrm{s}^{-1}$, the proportion of larvae retained in the vicinity of the adult population remains grossly unchanged around $3.5 \%$. Nevertheless, when the wind
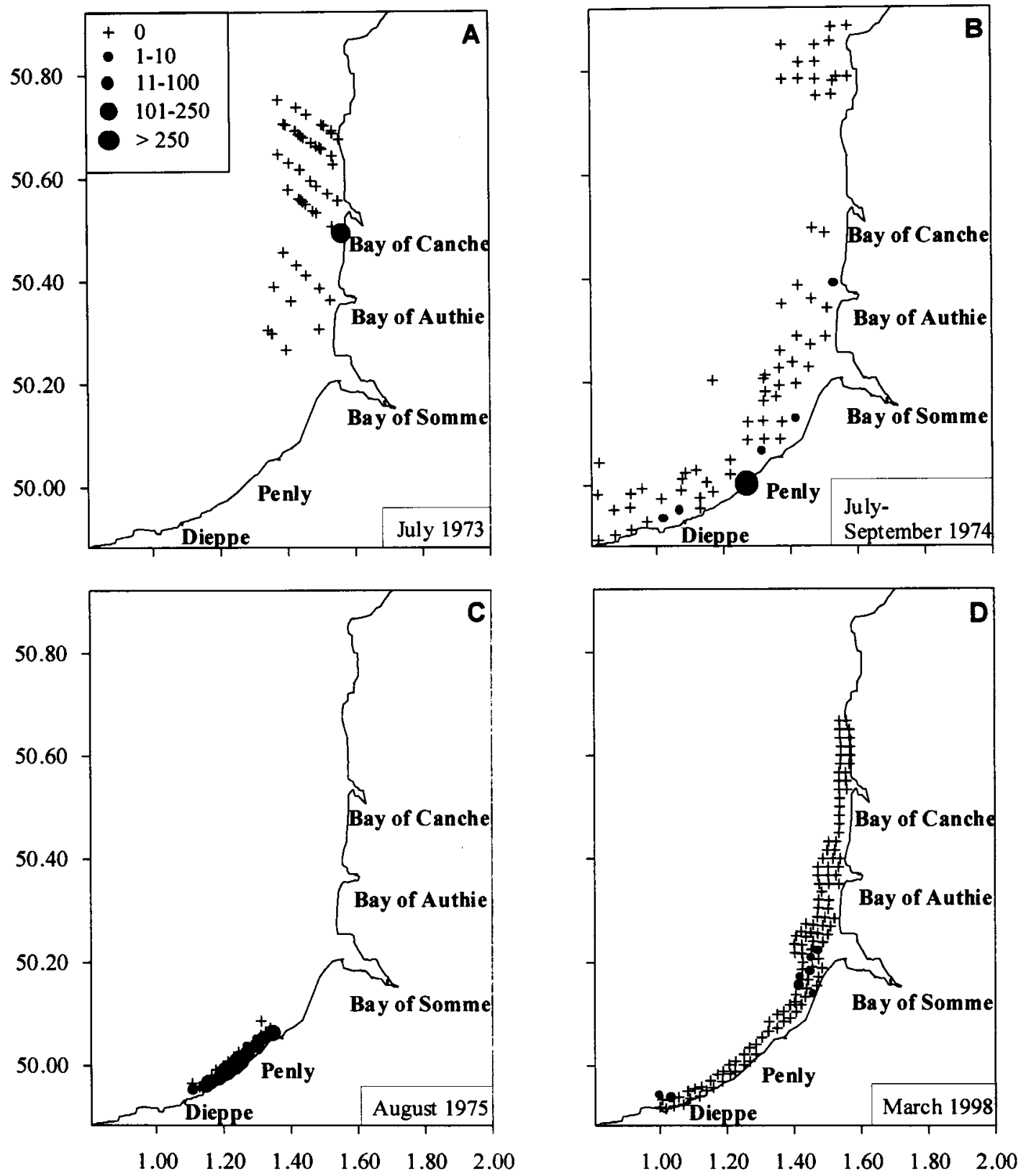

Figure 4. Distribution and densities of Pectinaria koreni in the Picarde Bay. (A) July 1973. (B) July-September 1974. (C) August 1975. (D) March 1998. Densities are expressed in ind. $(30 \mathrm{~L})^{-1}$ of sediment in 1973,1974 and 1975 and in ind. $\left(0.5 \mathrm{~m}^{2}\right)^{-1}$ in 1998. 

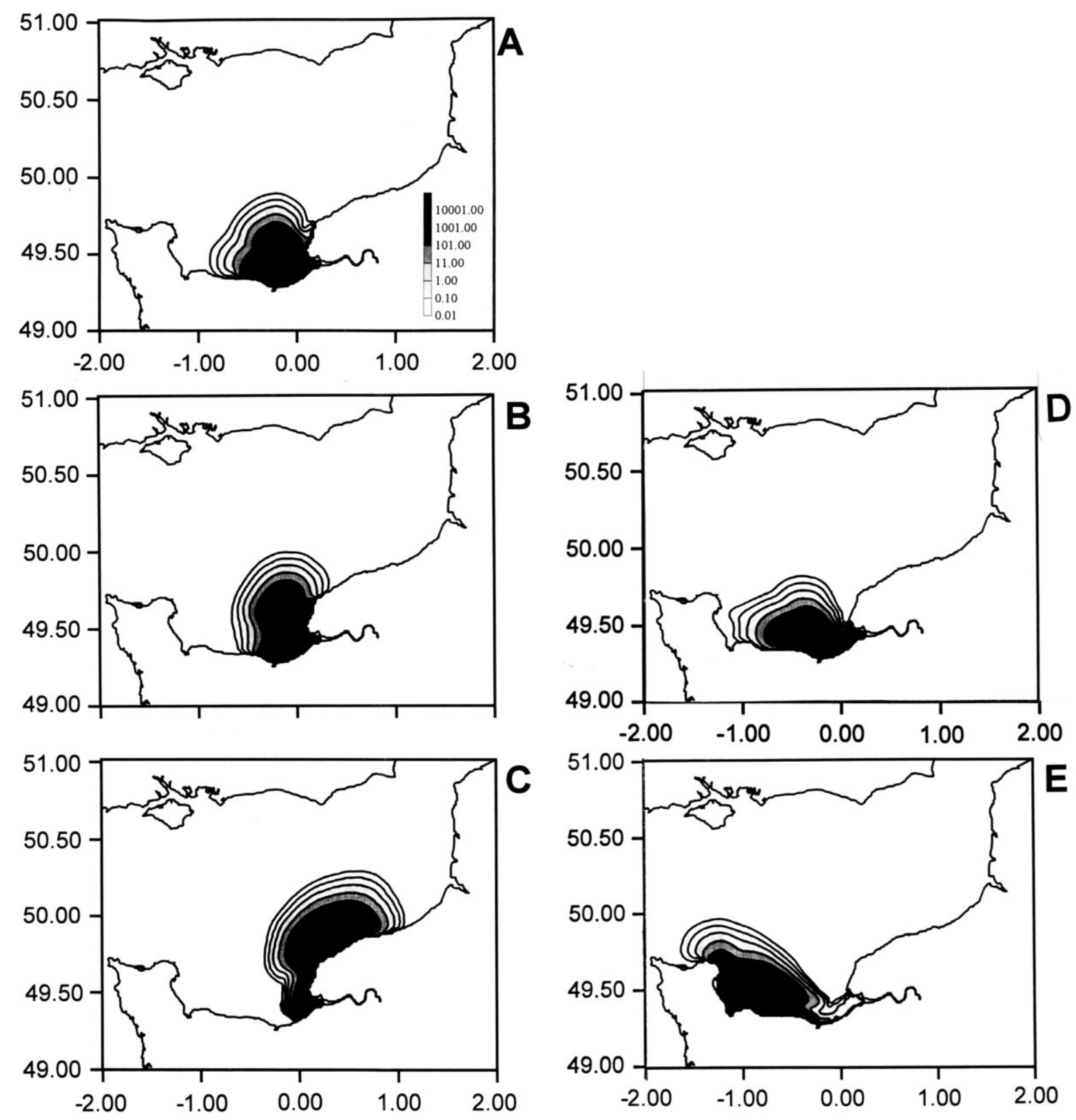

Figure 5. Simulated dispersion of a larval cohort resulting from the release of $10^{7}$ eggs $\cdot \mathrm{m}^{-2}$ in the eastern Bay of Seine after 15 days for an average tide. (A) without wind; (B) SW wind of $6 \mathrm{~m} \cdot \mathrm{s}^{-1}$; (C) SW wind of $12 \mathrm{~m} \cdot \mathrm{s}^{-1}$; (D) NE wind of $6 \mathrm{~m} \cdot \mathrm{s}^{-1}$; (E) NE wind of 12 $\mathrm{m} \cdot \mathrm{s}^{-1}$.

speed reaches $15 \mathrm{~m} \cdot \mathrm{s}^{-1}$, the proportion of larvae retained on the adult area increases to $6.69 \%$. In these climatic conditions, the larval panache comes back massively southwards so that the maximal larval abundance is concentrated above the favourable sub- strates of the Bay of Veys. For NE winds, the eddy structure is not altered as long as the wind intensity is not high (i.e. $3-6 \mathrm{~m} \cdot \mathrm{s}^{-1}$ ). When its speed exceeds 6 $\mathrm{m} \cdot \mathrm{s}^{-1}$, the gyre collapses and the larval panache is advected westwards, north of the Cotentin; it can 
even reach the norman-breton gulf when wind speed exceeds $9 \mathrm{~m} \cdot \mathrm{s}^{-1}$. Maximal larval densities are advected in the same way as the rest of the cohort even if a part of this maximum-density patch always remains along the eastern coast of the Cotentin. Nevertheless this
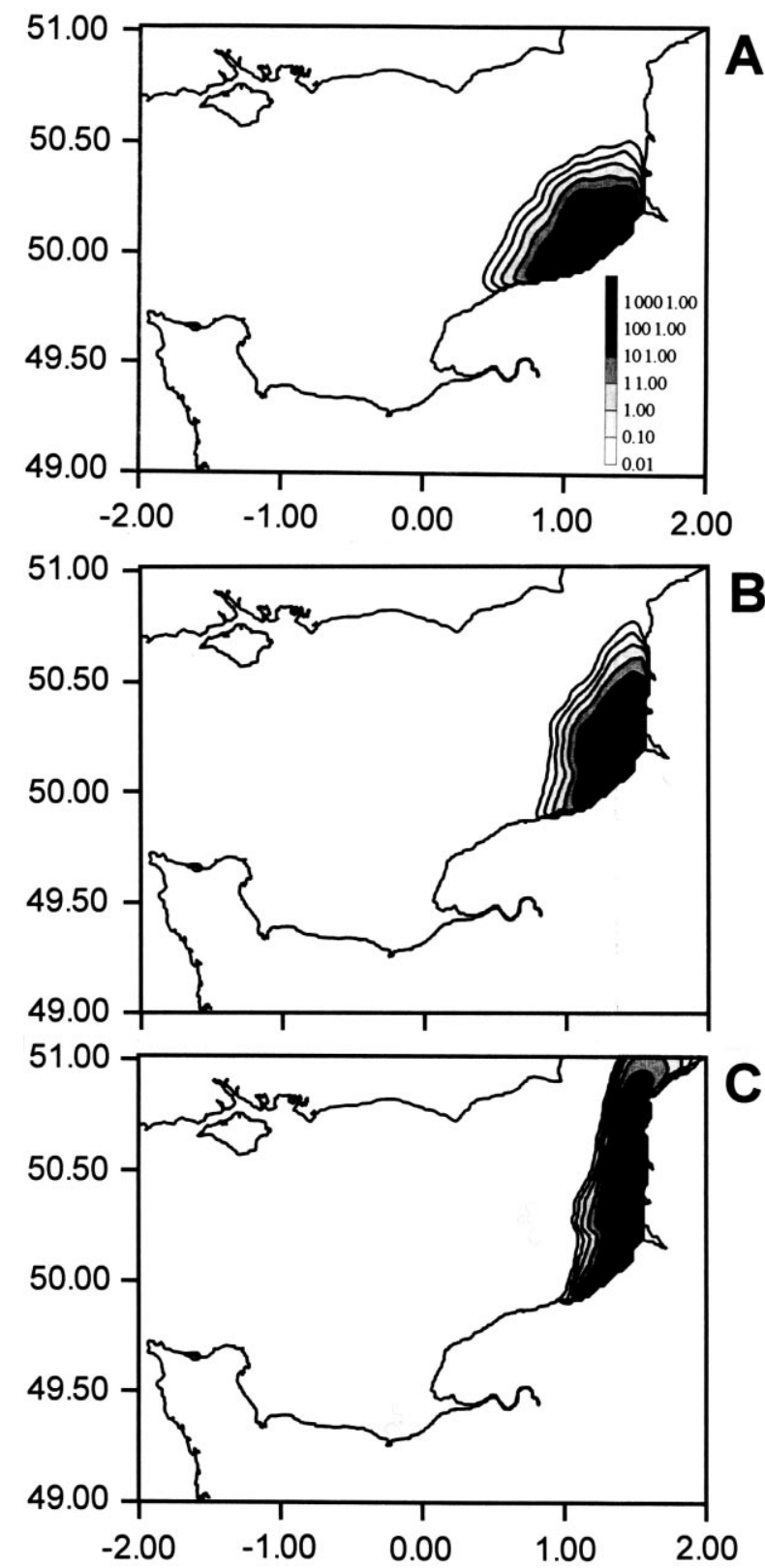

maximal larval density band becomes thinner when the wind speed increases, flushing the panache westwards. Thus larval retention decreases slightly when the NE wind intensity increases, from $3.54 \%$ for a NE wind of $3 \mathrm{~m} \cdot \mathrm{s}^{-1}$ to $1.24 \%$ for a NE wind of $15 \mathrm{~m} \cdot \mathrm{s}^{-1}$.

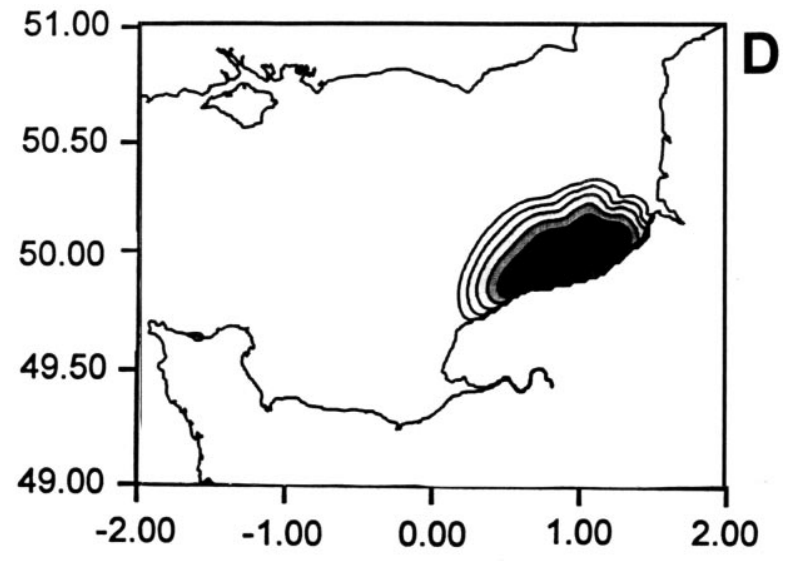

Figure 6. Simulated dispersion of a larval cohort resulting from the release of $10^{7}$ eggs $\cdot \mathrm{m}^{-2}$ in the Bay of Veys after 15 days for an average tide. (A) without wind; (B) SW wind of $6 \mathrm{~m} \cdot \mathrm{s}^{-1}$; (C) SW wind of $12 \mathrm{~m} \cdot \mathrm{s}^{-1}$; (D) NE wind of $6 \mathrm{~m} \cdot \mathrm{s}^{-1}$; (E) NE wind of $12 \mathrm{~m} \cdot \mathrm{s}^{-1}$. 
A larval cohort released from the Bay of Veys is able to colonise the favourable substrates of the Bay of Seine, but only for a SW wind of $15 \mathrm{~m} \cdot \mathrm{s}^{-1}$ during 15 consecutive days. The percentage of larvae reaching these substrates and settling is equal to $9 \times 10^{-3} \%$.

\subsubsection{Larval release from the Picarde Bay}

With no wind, the larval cohort released off Penly drifts along the coast both upstream and downstream from its source spawning area (figure 7). Maximal larval densities (i.e. $>10000$ larvae $\cdot \mathrm{m}^{-3}$ ) stay where they were released and $23.22 \%$ of the larval population is retained on the favourable substrates of the adult population (table III).

The wind forcing greatly affects the direction of larval dispersal and the magnitude of larval retention and settlement (figure 7; table III). For a SW wind, the larval cohort is transported northwards along the coasts of the Picarde Bay up to the North Sea, while it spreads southwestwards along the coasts of Pays de Caux for a NE wind. When the SW wind speed increases from 0 to $6 \mathrm{~m} \cdot \mathrm{s}^{-1}$, larval retention increases from 23.22 to $36.13 \%$ as larval panache remains above the favourable substrate for larval settlement during its drift along the coast between Penly and Boulogne sur mer. Afterwards, for a SW wind speed exceeding 6 $\mathrm{m} \cdot \mathrm{s}^{-1}$, the retention decreases from 36.13 to $8.00 \%$ as some larvae are exported toward the Southern Bight of the North Sea beyond model limits. For a NE wind the larval cohort is carried out of the suitable substrates of the Picarde Bay so that larval retention decreases when wind speed increases, from $21.48 \%$ for a wind of $6 \mathrm{~m} \cdot \mathrm{s}^{-1}$ to $0.04 \%$ for a wind of $15 \mathrm{~m} \cdot \mathrm{s}^{-1}$.

Larvae released off Penly are able to colonise favourable substrates located in the Southern Bight of the North Sea off Gravelines [32], for SW winds $\geq 9$ $\mathrm{m} \cdot \mathrm{s}^{-1}$, in proportions ranging between $10^{-5}$ and $2.86 \%$ (table III). Likewise, the larval plume can reach the favourable substrates of the eastern Bay of Seine for a NE wind $\geq 9 \mathrm{~m} \cdot \mathrm{s}^{-1}$ during 15 consecutive days. In this case, the percentage of larvae reaching these substrates at the end of the dispersive phase varied from $4 \times 10^{-5}$ to $39.19 \%$. One can note that the colonisation rates exceed the retention rates for wind speeds $\geq 12 \mathrm{~m} \cdot \mathrm{s}^{-1}$.

For a release point off the Bay of Somme, larval dispersal patterns are similar to those reported from Penly (figure 8 ). Without wind, the percentage of larval retention is equal to $40.78 \%$ (table III). When the SW wind speed exceeds $3 \mathrm{~m} \cdot \mathrm{s}^{-1}$, the larval retention decreases from $37.30 \%$ for $6 \mathrm{~m} \cdot \mathrm{s}^{-1}$ to $6.37 \%$ for 15 $\mathrm{m} \cdot \mathrm{s}^{-1}$. For NE winds, the retention decreases when the wind speed increases from $40.20 \%$ for a speed of 3 $\mathrm{m} \cdot \mathrm{s}^{-1}$ to $1.73 \%$ for a speed of $15 \mathrm{~m} \cdot \mathrm{s}^{-1}$.

Larvae released off the Bay of Somme are able to colonise the favourable substrates off Gravelines for SW winds $\geq 9 \mathrm{~m} \cdot \mathrm{s}^{-1}$ (percentage of colonisation ranging between 1.29 and $3.69 \%$ ), and those of the eastern Bay of Seine for NE winds of $15 \mathrm{~m} \cdot \mathrm{s}^{-1}$ (percentage of colonisation equal to $7.27 \%$ ) (table III).

When larvae are released off the Canche Bay larval dispersal patterns, with or without wind, are almost the same as previously described (figure 8). The main difference resides in a higher spreading out of the larval plume offshore to the west. The proportion of larvae retained on the adult area has been quantified to 3.48 $\%$ without wind (table III). When the SW wind speed exceeds $3 \mathrm{~m} \cdot \mathrm{s}^{-1}$, the proportion of retained larvae decreases from $1.90 \%$ for $6 \mathrm{~m} \cdot \mathrm{s}^{-1}$ to $0.06 \%$ for 15 $\mathrm{m} \cdot \mathrm{s}^{-1}$ as larvae are exported to the North Sea. For NE winds, the larval retention is enhanced from 3.48 to $24.82 \%$ when the wind speed increases from 0 to 9 $\mathrm{m} \cdot \mathrm{s}^{-1}$. Conversely, for a NE wind ranging between 9 and $15 \mathrm{~m} \cdot \mathrm{s}^{-1}$, the retention decreases from 24.82 to $1.05 \%$. In these latter wind conditions, the larval plume spreads southwestwards beyond the favourable substrates of the Picarde Bay.

Larvae released off the Canche Bay can colonise the favourable substrates off Gravelines for a SW wind $\geq 3 \mathrm{~m} \cdot \mathrm{s}^{-1}$, at a rate which varied between $10^{-3}$ and $2.80 \%$. The maximal colonisation rate occurs for a wind speed of $9 \mathrm{~m} \cdot \mathrm{s}^{-1}$. When the wind speed exceeds $9 \mathrm{~m} \cdot \mathrm{s}^{-1}$, the larval panache is flushed toward the North Sea beyond the favourable substrates off Gravelines. These larvae are also able to colonise the favourable substrates of the eastern Bay of Seine for NE winds of $15 \mathrm{~m} \cdot \mathrm{s}^{-1}$ during 15 consecutive days at a low rate of colonisation $(0.01 \%$ ) (table III).

\section{DISCUSSION-CONCLUSION}

\subsection{Intersite diversity of larval dispersal}

Larval dispersal patterns depend on the relative importance of advection and turbulent diffusion at the 

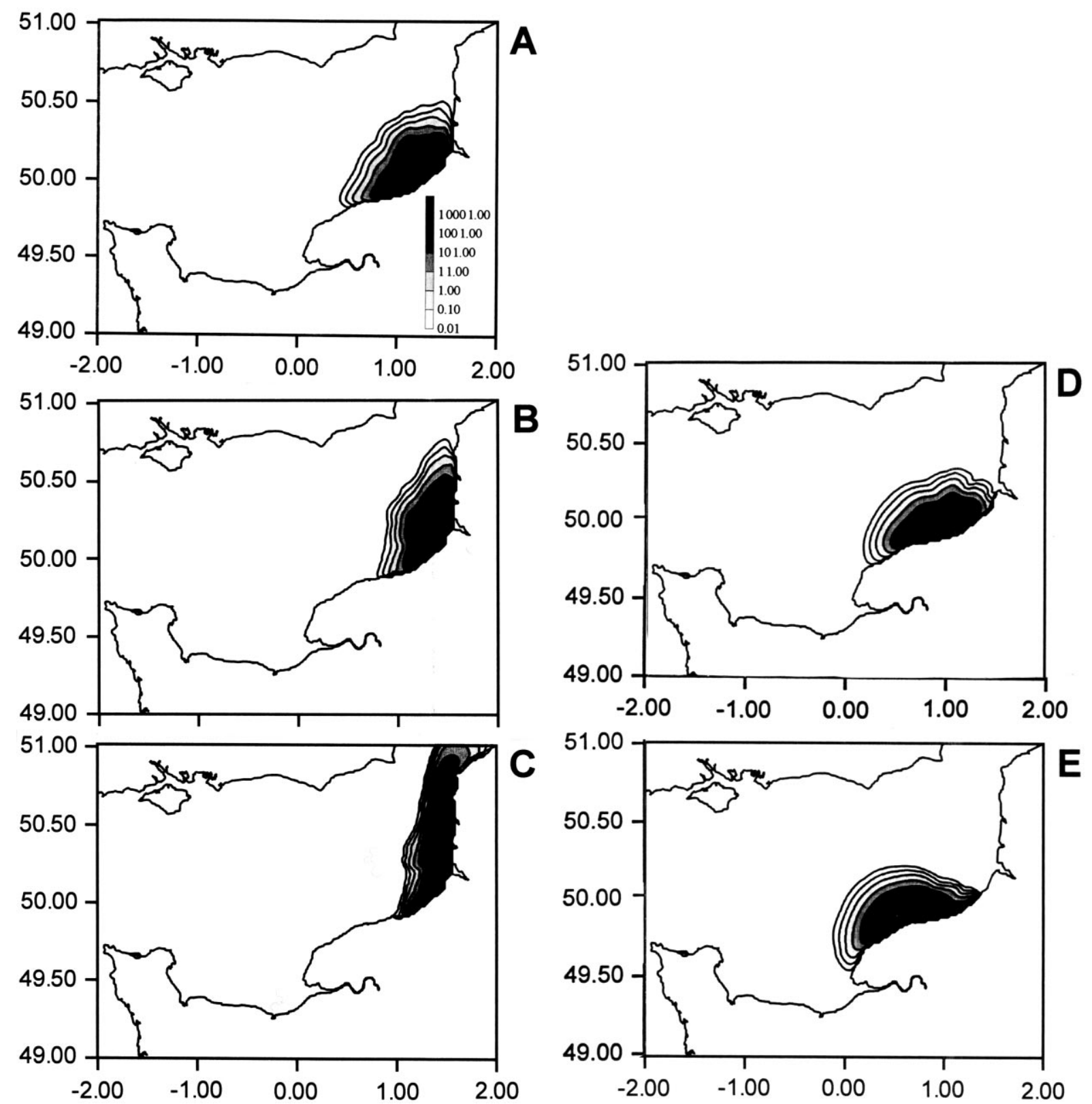

Figure 7. Simulated dispersion of a larval cohort resulting from the release of $10^{7}$ eggs $\mathrm{m}^{-2}$ off Penly after 15 days for an average tide. (A) without wind; (B) SW wind of $6 \mathrm{~m} \cdot \mathrm{s}^{-1}$; (C) SW wind of $9 \mathrm{~m} \cdot \mathrm{s}^{-1}$; (D) NE wind of $6 \mathrm{~m} \cdot \mathrm{s}^{-1}$; (E) NE wind of $9 \mathrm{~m} \cdot \mathrm{s}^{-1}$.

site of larval release $[19,33]$. Where the advective residual velocity is weak, it can hardly exceed the diffusion effects. A preferential direction of movement exists but diffusion makes it possible for larvae to proceed in all directions from the location of the adult population and even backwards against the prevailing currents. This gives the larvae the opportu- nity to remain in the vicinity of the adult populations in significant numbers which may allow autorecruitment. Conversely, if the residual velocity is strong enough, larvae are carried away from their release point. For them to remain in the same place, it is necessary that the trajectory be closed and gone through in a time span similar to the larval lifetime. 
From both the atlas of residual currents due to tidal and wind forcing in the English Channel [36] and the results of the present simulations, it is possible to determine for each Pectinaria koreni population in the eastern English Channel, the relative effects of the advective and diffusive processes on larval dispersal.
According to the predicted flow field due to tidal forcing, three patterns can be distinguished:

1. diffusion dominance (i.e. low tidal advection low diffusion). Despite its weakness, the turbulent diffusion is the dominant process controlling larval dispersal off Penly, off the Bay of Somme and

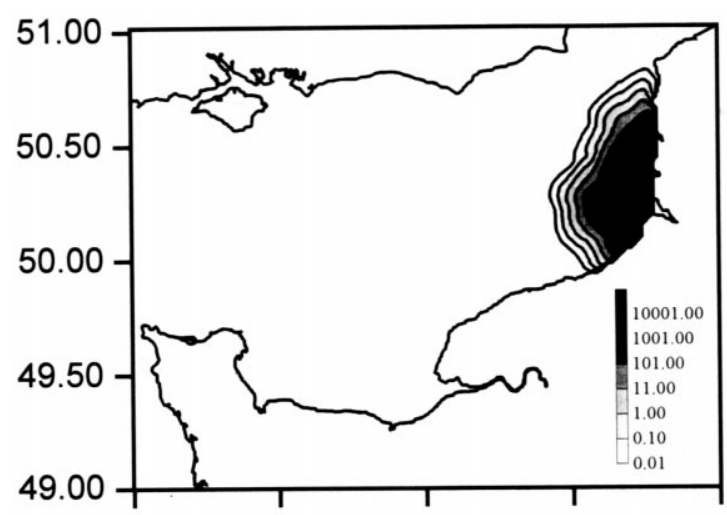

\section{A}
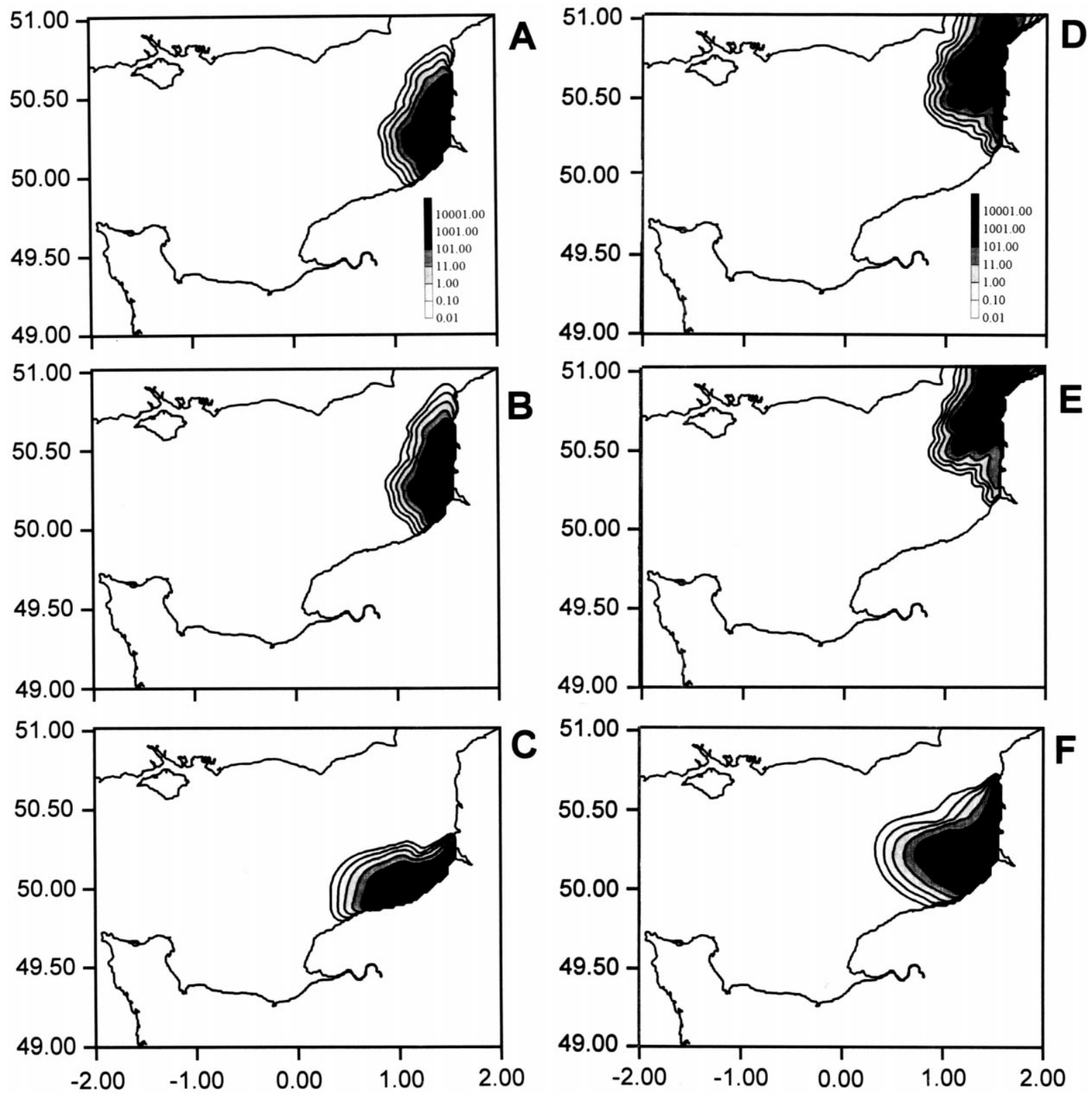

Figure 8. Simulated dispersion of a larval cohort resulting from the release of $10^{7}$ eggs $\cdot \mathrm{m}^{-2}$ off the Bay of Somme and off the Canche estuary after 15 days for an average tide. (A) Bay of Somme - without wind; (B) Bay of Somme - SW wind of $3 \mathrm{~m} \cdot \mathrm{s}^{-1}$; (C) Bay of Somme - NE wind of $9 \mathrm{~m} \cdot \mathrm{s}^{-1}$; (D) Canche estuary - without wind; (E) Canche estuary - SW wind of $3 \mathrm{~m} \cdot \mathrm{s}^{-1}$; (F) Canche estuary - NE wind of $9 \mathrm{~m} \cdot \mathrm{s}^{-1}$. 
in the eastern Bay of Seine. In the two former sites where residual current velocities are about 1 and $1-3 \mathrm{~cm} \cdot \mathrm{s}^{-1}$ respectively diffusion explains why the larval panache spreads both upstream and downstream of the release point. In the eastern Bay of Seine, larval dispersal is mainly isotropic in relation to diffusive processes even if residual currents $\left(1-3 \mathrm{~cm} \cdot \mathrm{s}^{-1}\right)$ induce a larval transport preferentially to the west and the northwest.

2. advection dominance (i.e. high tidal advection low to high diffusion). From the Bay of Veys, larvae are carried along the Cotentin coasts to Barfleur by residual currents of $3-15 \mathrm{~cm} \cdot \mathrm{s}^{-1}$ and then trapped in a gyre. The increase of turbulent diffusion north and east of Barfleur enables a spreading out of the larval cohort within the gyre.

3. advection-diffusion dominance (i.e. moderate tidal advection - moderate diffusion). Off the Canche estuary, larvae are mainly advected northwards to the Dover Strait by residual currents of 3-7 $\mathrm{cm} \cdot \mathrm{s}^{-1}$ while an increase of turbulent diffusion west of the estuary induces a large spreading out of larvae offshore.

Wind-induced currents may be greater than tidal residual ones, depending both on the tidal advection strength and on the wind direction and intensity [36] and modify the relative importance of advective and diffusive processes, and consequently larval dispersal patterns. The wind effect gets stronger as advection weakens. In sites where tidal residual advection is weak $\left(\leq 3 \mathrm{~cm} \cdot \mathrm{s}^{-1}\right)$, wind enhances the role of advective processes by increasing the velocity of residual currents by a factor 2 to 4 . As an example, in the eastern Bay of Seine and off Penly, residual currents vary between 5 and $11 \mathrm{~cm} \cdot \mathrm{s}^{-1}$, and 3 and $7 \mathrm{~cm} \cdot \mathrm{s}^{-1}$ for a NE wind and a SW wind of $8 \mathrm{~m} \cdot \mathrm{s}^{-1}$ respectively [36]. Wind-induced currents increase the extent of larval dispersal plume. According to its direction wind will either strengthen tidal advection if the two processes act in the same direction (e.g. SW wind in the Picarde Bay) or on the contrary negate tidal advection if they act in opposite directions (e.g. SW wind in the eastern Bay of Seine). The relative importance of wind-induced currents and tidal residual currents will depend on the wind intensity, which has to be greater than a threshold value to counteract the tidal effect.

When tidal advection is strong, as in the Bay of Veys, the influence of wind on the larval dispersal lessens, even if the dispersal area increases. A NE wind slightly increases the tidal residual currents but it disrupts the tidally-induced gyre off Barfleur when it is strong enough $\left(\geq 9 \mathrm{~m} \cdot \mathrm{s}^{-1}\right)$. On the contrary, a SW wind $\geq 9 \mathrm{~m} \cdot \mathrm{s}^{-1}$ decreases the tidal advection effect (i.e. the residual current speed ranges between 1 and $7 \mathrm{~cm} \cdot \mathrm{s}^{-1}$ along the Cotentin coasts) and displaces the eddy structure southwards.

\subsection{Retention and colonisation schemes}

For all emission sites and meteorological conditions, the simulation results show larval retention levels which vary among sites and according to wind direction and intensity. On the other hand, pelagic dispersal under particular wind conditions leads to opportunities for colonisation of distant muddy fine sand patches. In some cases, the proportion of larvae reaching other suitable substrates even exceeds the proportion staying on the emission site:

1. the colonisation of the eastern Bay of Seine by larvae from the Picarde Bay for NE wind $\geq 12$ $\mathrm{m} \cdot \mathrm{s}^{-1}$,

2. the colonisation of the Bay of Veys by larvae from the eastern Bay of Seine for NE wind $\geq 15 \mathrm{~m} \cdot \mathrm{s}^{-1}$

3. the colonisation of the Picarde Bay by larvae from the eastern Bay of Seine for SW wind $\geq 15$ $\mathrm{m} \cdot \mathrm{s}^{-1}$.

These possibilities of colonisation allow a reduction of the larval loss during dispersal although they generally require exceptional wind conditions: a uniform and intense wind during 15 consecutive days.

Retention and colonisation patterns are a function of local hydrodynamic characteristics [19], adult habitat size [19] and inter-annual variability of climatic conditions [2, 46]. Using a simple advection-diffusionmortality model, Hill [19] argued that level of turbulent diffusion on the European shelf causes insufficient larval losses to affect larval settlement for a benthic population, while moderate advection (4-5 $\mathrm{cm} \cdot \mathrm{s}^{-1}$ ) generates a drastic decrease in larval retention. This author has also shown that for a given larval life duration and hydrodynamic conditions, a minimal size of adult habitat could be defined below which no larval retention occurs. Predicted larval distribution for the three Pectinaria koreni populations of the French coasts of the English Channel 
conform partly to such assumptions. In areas characterized by low tidal residual currents (eastern Bay of Seine and off the Bay of Somme), a high larval retention (58.05 and $40.78 \%$ respectively) was reported as some larvae are able to spread back towards the adult area against the prevailing currents. The increase of residual currents in response to wind forcing reduce by several orders of magnitude larval retention in these sites but favour larval colonisation of neighbouring suitable substrates. From field studies in the eastern Bay of Seine on Pectinaria koreni larvae, Lagadeuc [23] has previously observed that wind-induced currents are the major source of variability of larval transport in coastal zones of the English Channel.

Despite low to moderate tidal residual currents, larval retention from a larval release off Penly and off the Canche estuary remains low (23.22 and 3.48\% respectively) compared to a release off the Bay of Somme or from the eastern Bay of Seine. As these larval emission sites are located at the southern and northern limits of the adult habitat, most larvae are dispersed over unsuitable substrates. By enhancing advective processes in one direction along a coastal band, wind-induced currents would favour either larval retention (i.e. release off Penly for a SW wind and off the Canche estuary for a NE wind) or larval colonisation of distant populations (release off Penly for a NE wind and off the Canche estuary for a SW wind).

In the Bay of Veys, according to the smaller size of the adult habitat and the higher residual circulation, larval retention is lower than that calculated in the two previous sites but is not negligible (around $3.5 \%)$.

Interannual climatic variations have a strong influence on larval dispersal patterns and settlement so that year-to-year variations in prevailing winds can leave annual signatures on population structure. In Narragansett Bay, USA, Bertness et al. [2], found that spatial and temporal variation in settlement of the acorn barnacle is strongly correlated with wind direction from daily to annual scale. McConnaughey et al. [28], showed also the strong influence of wind on larval dispersal of the crab Cancer magister so that settlement along the southern Washington coasts is heavier the years when the net Ekman transport is landward. During Pectinaria koreni reproductive pe- riod (April-June) for 1962-1997, wind observations at La Hève Cape (eastern Bay of Seine) revealed that $\mathrm{N}-\mathrm{NE}$ and $\mathrm{W}-\mathrm{SW}$ winds blew between 21 and $57 \%$, and 17 and $49 \%$ of the time respectively (MeteoFrance data). Assuming that these data are representative of the global wind regime of the eastern English Channel, such an inter-annual variability of wind dominance could greatly affect larval retention within each site and the abilities of colonisation of distant populations between years.

\subsection{Functional structure of the Pectinaria koreni populations}

Predicted larval dispersal shows that each of the three Pectinaria koreni populations can be self-sustained as larval retention is generally more important than larval immigration from distant sites. Despite sizeable larval losses, retention at the end of the larval phase could generally maintain more organisms on suitable substrates than are necessary to sustain the local population. As an example, larval retention in the eastern Bay of Seine ranges between 1.02 and $58.05 \%$ for low to moderate winds ( $\leq 9 \mathrm{~m} \cdot \mathrm{s}^{-1}$ ), which corresponds to settler densities of 17600 and 999900 ind. $\mathrm{m}^{-2}$ respectively for a adult habitat of $400 \mathrm{~km}$. Conversely, on the same site, the density of settlers drops sharply to $35 \mathrm{ind} . \mathrm{m}^{-2}$ for a NE wind of 15 $\mathrm{m} \cdot \mathrm{s}^{-1}$.

Larval colonisation from one population to another one may also occur. Larval colonisation may result from larval fluxes induced by exceptional wind conditions (e.g. from the eastern Bay of Seine to the Bay of Veys for a NE wind $\geq 9 \mathrm{~m} \cdot \mathrm{s}^{-1}$, from the eastern Bay of Seine to the Picarde Bay for a SW wind $\geq 12$ $\mathrm{m} \cdot \mathrm{s}^{-1}$ ). Such fluxes should be quite rare as NE and SW wind speeds during Pectinaria koreni reproductive period were commonly $<10 \mathrm{~m} \cdot \mathrm{s}^{-1}$ (MeteoFrance data). Conversely, at the Picarde Bay site where the Pectinaria koreni population is patchily distributed within the muddy fine sand community, simulations highlight usual larval exchanges between these patches (off Penly, off the Bay of Somme, off the Canche estuary) which occur under moderate wind conditions $\left(\leq 6 \mathrm{~m} \cdot \mathrm{s}^{-1}\right)$. In this case, we can hypothesize that larvae constitute a common pool moving along a coastal band and settling preferentially in one area depending on wind direction and speed. Such transport has been previously reported 
by Lagadeuc and Brylinski [22] who argued that the recruitment of the polychaete Polydora ciliata off Boulogne/mer is influenced by larval supply from a population situated $70 \mathrm{~km}$ to the south.

The three Pectinaria koreni populations along the French coasts of the eastern English Channel can be defined as a metapopulation (sensu [3]), since they consist of "a number of subpopulations of adults distributed along a coast, linked by dispersal of planktonic larval stage". The functional structure of the metapopulation showing local larval retention and larval fluxes between sites according to all simulated wind conditions is summarized in figure 9.

\subsection{Relative importance of pre- and post-settlement} processes

The field observations of adult stocks have shown a relative year-to-year stability in terms of density and distribution of the Pectinaria koreni population in the eastern Bay of Seine, as opposed to the year-to-year instability of the Bay of Veys and Picarde Bay populations. Despite significant larval retention for all populations, the differences in the long-term fluctuations of Pectinaria koreni populations between the different studied sites can not be explained primarily by larval supply.

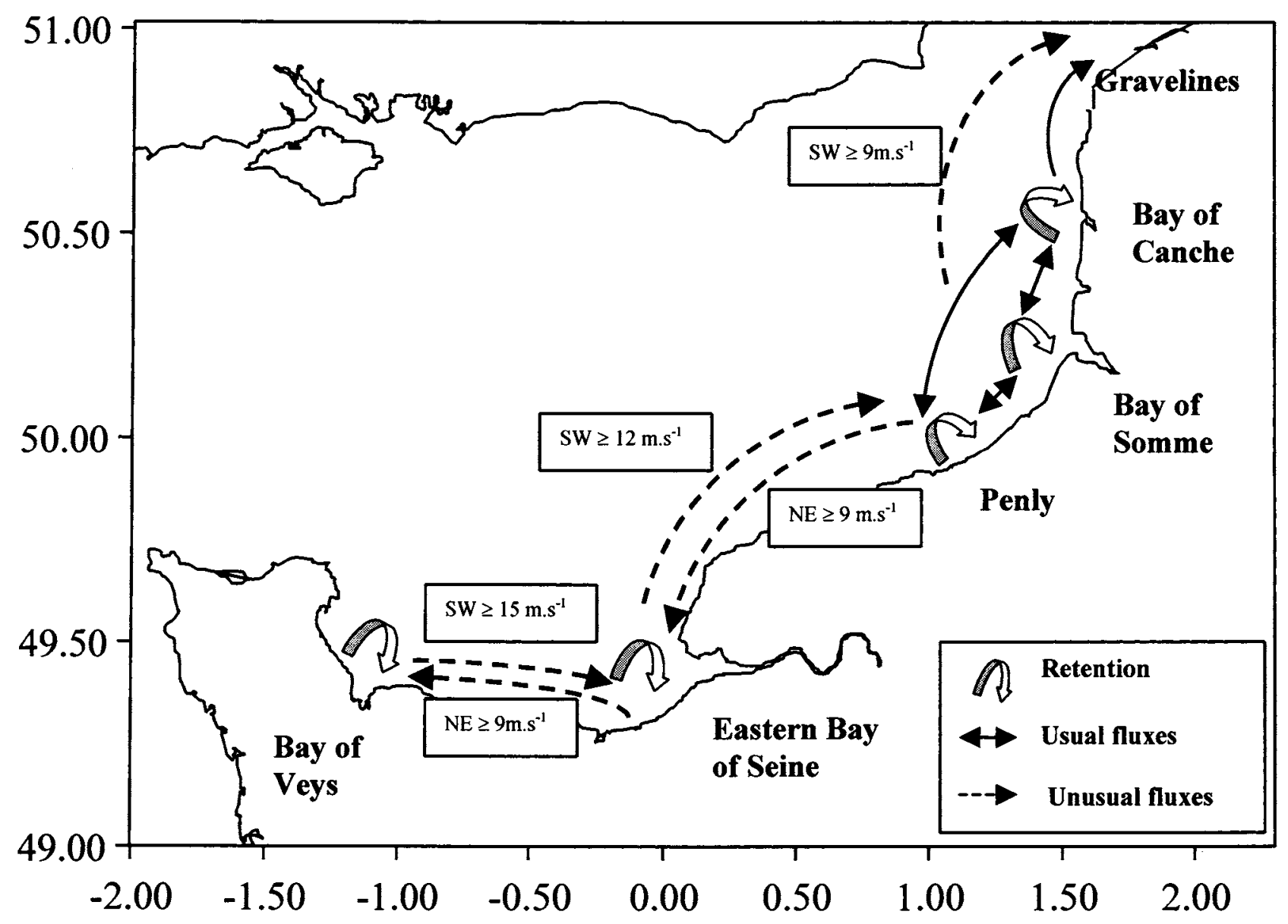

Figure 9. Schematic representation of the functional structure of Pectinaria koreni populations along the French coasts of the eastern English Channel, illustrating larval retention and colonisation. The meteorological conditions given indicate threshold values of wind speed inducing unusual fluxes between distant populations. 
In the eastern Bay of Seine, the adult population is distributed in patches of high abundance which cover areas of a few square kilometres off the Seine estuary and Deauville [26, 41]. Field studies however have shown that larval settlement occurs with the same intensity over the whole muddy fine sand community [26]. Although a minimal larval retention is determinant to explain adult population stability, Thiébaut et al. [41] argued that post-settlement processes including post-larval dispersal [31] and adult-juvenile interactions [8] are the primary factors controlling population distribution. Therefore, post-settlement processes would be a key factor to explain year-to-year fluctuations of adult densities for the three studied Pectinaria koreni populations. While most recent studies on the importance of larval supply to adult population limitation and regulation have focused on rocky shore communities [11, 12, 29], several authors have emphasised the significant role of post-settlement processes for soft sediment communities [30] or subtidal epifaunal fouling assemblages [43]. For soft-sediment communities, Olafsson et al. [30] have cited four main processes which can operate to regulate density of invertebrates: predation, adult-juvenile interactions, physical disturbance and food limitation. Due to the lack of knowledge on long-term variations of abiotic and biotic parameters in the Bay of Veys and along the Picarde estuaries, we cannot determine which post-settlement processes are mainly involved. To conclude, as transport of larvae between sites is rare, larval retention within a site is the predominant process for repopulation from one year to another. Despite yearto-year variations in larval supply according to climatic conditions, post-settlement processes may regulate primarily the adult population abundance and distribution. Over the long-term occasional larval transport between sites may be involved in the reestablishment of depleted populations and for the maintenance of genetic similarity among local populations.

\section{Acknowledgements}

This work was carried out as a part of the contribution of the Groupement de Recherches Manche to the Programme National sur le Déterminisme du Recrutement (PNDR-GLOBEC France). The authors are grateful to Louis Cabioch for providing 1970s benthic data, and the crews of NO Pluteus II, NO Côtes d'Aquitaine and NO Côtes de la Manche for their valuable assistance in field work. They also acknowledge Paul Nival, Louis Cabioch and one anonymous referee for their useful comments on the first draft of this manuscript and Philippe Guyard (University of Southampton) for his help in correcting the English text.

\section{REFERENCES}

[1] Barnay A.-S., Variabilité spatio-temporelle de l'effort de reproduction de Pectinaria koreni et conséquences sur le recrutement en Baie de Seine orientale, DEA Océanologie biologique et Environnement marin, Univ. Paris VI (1999) $32 \mathrm{p}$.

[2] Bertness M.D., Gaines S.D., Wahle R.A., Wind-driven settlement patterns in the acorn barnacle Semibalanus balanoides, Mar. Ecol. Prog. Ser. 137 (1996) 103-110.

[3] Botsford L.W., Moloney C.L., Hastings A., Largier J.L., Powell T.M., Higgins K., Quinn J.F., The influence of spatially and temporally varying oceanographic conditions on mesoplanktonic metapopulations, Deep-Sea Res. II 41 (1994) 107-145.

[4] Breton M., Salomon J.-C., A 2D long term advection-dispersion model for the Channel and Southern North Sea, Part A: Validation through comparison with artificial radionuclides, J. Mar. Syst. 6 (1995) 495-513.

[5] Cabioch L., Glaçon R., Distribution des peuplements benthiques en Manche orientale, de la baie de Somme au Pas-de-Calais, C. R. Acad. Sci. Paris 280D (1975) 491-494.

[6] Cabioch L., Glaçon R., Distribution des peuplements benthiques en Manche orientale, du cap d'Antifer à la baie de Somme, C. R. Acad. Sci. Paris 285D (1977) 209-212.

[7] Cabioch L., Gentil F., Glaçon R., Retière C., Le macrobenthos des fonds meubles de la Manche: distribution générale et écologie, in: Keegan B.F., O'Ceidigh P., Boaden P.J.S. (Eds.), Biology of benthic organisms, Proc. 11th EMBS, Pergamon Press, Oxford, 1977, pp. 115-128.

[8] Desroy N., Olivier F., Retière C., Effects of individual behaviors, inter-individual interactions with adult Pectinaria koreni and Owenia fusiformis (Annelida, Polychaeta), and hydrodynamism on Pectinaria koreni recruitment, Bull. Mar. Sci. 60 (1997) $547-558$.

[9] Elkaïm B., Irlinger J.-P., Contribution à l'étude de la dynamique des populations de Pectinaria koreni (Malmgren) (Polychète) en baie de Seine orientale, J. Exp. Mar. Biol. Ecol. 107 (1987) 171-197.

[10] Ellien C., Modélisation du transport larvaire en Manche orientale et conséquences sur le recrutement: application à la population de Pectinaria koreni (Annélide, Polychète) en baie de Seine, DEA océanologie biologique et environnement marin, Univ. Paris VI (1997) 43 p.

[11] Gaines S.D., Rougharden J., Larval settlement rate: a leading determinant of structure in an ecological community of the marine intertidal zone, Proc. Natl. Acad. Sci. USA 82 (1986) 3707-3711.

[12] Gaines S.D., Bertness M.D., Dispersal of juveniles and variable recruitment in sessile marine species, Nature 360 (1992) 579-580.

[13] Gaines S.D., Bertness M.D., The dynamics of juvenile dispersal: why field ecologists must integrate?, Ecology 74 (1993) 24302435. 
[14] Garvine R.W., Epifanio C.E., Epifanio C.C., Wong K.-C., Transport and recruitment of blue crab larvae: a model with advection and mortality, Est. Coast. Shelf Sci. 45 (1997) 99-111.

[15] Gentil F., Irlinger J.-P., Elkaïm B., Proniewski F., Premières données sur la dynamique du peuplement macrobenthique des sables fins envasés à Abra alba de la Baie de Seine orientale, Actes Colloq. Ifremer 4 (1986) 409-420.

[16] Gentil F., Cabioch L., Carte des peuplements macrobenthiques de la baie de Seine et Manche centrale sud, Ed. Stat. Biol. Roscoff, 1997.

[17] Guéguéniat P., Bailly du Bois P., Salomon J.-C., Masson M., Cabioch L., Fluxmanche radiotracers measurements: a contribution to the dynamics of the English Channel and North Sea, J. Mar. Syst. 6 (1995) 483-494.

[18] Günther C.-P., Dispersal of intertidal invertebrates: a strategy to react to disturbances of different scales? Neth. J. Sea Res. 30 (1992) 45-56.

[19] Hill A.E., Pelagic dispersal of Norway lobster Nephrops norvegicus larvae examined using an advection-diffusion-mortality model, Mar. Ecol. Prog. Ser. 64 (1990) 217-226.

[20] Hill A.E., Horizontal zooplankton dispersal by diel vertical migration in $\mathrm{S}_{2}$ tidal currents on the northwest European continental shelf, Cont. Shelf Res. 14 (1994) 491-506.

[21] Irlinger J.-P., Gentil F., Quintino V., Reproductive biology of the polychaete Pectinaria koreni (Malmgren) in the Bay of Seine (English Channel), Ophelia Suppl. 5 (1991) 343-350.

[22] Lagadeuc Y., Brylinski J.-M., Transport larvaire et recrutement de Polydora ciliata (Annélide, Polychète) sur le littoral boulonnais, Cah. Biol. Mar. 28 (1987) 537-550.

[23] Lagadeuc Y., Répartition verticale des larves de Pectinaria koreni en baie de Seine orientale: influence sur le transport et le recrutement, Oceanol. Acta 15 (1992) 95-104.

[24] Lagadeuc Y., Transport larvaire en Manche, exemple de Pectinaria koreni en Baie de Seine, Oceanol. Acta 15 (1992) 383-395.

[25] Lagadeuc Y., Retière C., Critères d'identification rapide des stades de développement des larves de Pectinaria koreni (Malmgren) (Annélide Polychète) de la baie de Seine (Manche), Vie Milieu 43 (1993) 217-224.

[26] Lambert R., Recrutement d'espèces benthiques à larves pélagiques en régime mégatidal, Cas de Pectinaria koreni (Malmgren), annélide polychète, thèse Univ. Rennes I, 1991, 176 p.

[27] Larsonneur C., Bouysse P., Auffret J.-P., The superficial sediments of the English Channel and its western approaches, Sedimentology 29 (1982) 851-864.

[28] McConnaughey R.A., Armstrong D.A., Hickey B.M., Dungeness crab (Cancer magister) recruitment variability and Ekman transport of larvae, ICES mar. Sci. Symp. 199 (1995) 167-174.

[29] Minchinton T.E., Scheibling R.E., The influence of larval supply and settlement on the population structure of barnacles, Ecology 72 (1991) 1867-1879.

[30] Olafsson E.B., Peterson C.H., Ambrose W.G., Does recruitment limitation structure populations and communities of macro-invertebrates in marine soft sediments: the relative significance of pre- and post-settlement processes, Oceanogr. Mar. Biol. Ann. Rev. 32 (1994) 65-109.
[31] Olivier F., Vallet C., Dauvin J.-C., Retière C., Drifting in post-larvae and juveniles in an Abra alba (Wood) community of the eastern part of the Bay of Seine (English Channel), J. Exp. Mar. Biol. Ecol. 199 (1996) 89-109.

[32] Prygiel J., Davoult D., Dewarumez J.-M., Glaçon R., Richard A., Description et richesse des peuplements benthiques de la partie française de la mer du Nord, C.R. Acad. Sci. Paris 306 série III (1988) 5-10.

[33] Salomon J.-C., Role of instantaneous and long-term water movements on the recruitment and life of benthic fauna in the English Channel, La mer 28 (1990) 211-217.

[34] Salomon J.-C., Guéguéniat P., Orbi A., Baron Y., A Lagrangian model for long-term tidally-induced transport and mixing. Verification by artificial radionuclide concentrations, in: Guary J.-C., Guéguéniat P., Pentreath R.J. (Eds), Radionuclides : a tool for oceanography, Elsevier, 1988, pp. 384-394.

[35] Salomon J.-C., Breton M., Courants résiduels de marée dans la Manche, Oceanol. Acta sp. 11 (1991) 47-53.

[36] Salomon J.-C., Breton M., An atlas of long-term currents in the Channel, Oceanol. Acta 16 (1993) 439-448.

[37] Salomon J.-C., Breton M., Guéguéniat P., Computed residual flow through the Strait of Dover, Oceanol. Acta 16 (1993) $449-455$.

[38] Salomon J.-C., Garreau P., Breton M., The Lagrangian barycentric method to compute $2 \mathrm{D}$ and $3 \mathrm{D}$ long term dispersion in tidal environments, in: Pattiaratchi C. (Ed.), Mixing processes in estuaries and coastal seas, Am. Geophys. Un. 1996, pp. 59-76.

[39] Scheltema R.S., On dispersal and planktonic larvae of benthic invertebrates: an eclectic overview and summary of problems, Bull. Mar. Sci. 39 (1986) 290-322.

[40] Shanks A.L., Mechanisms of cross-shelf dispersal of larval invertebrates and fish, in: McEdward L. (Ed.), Ecology of marine Invertebrate larvae, CRC Press, 1995, pp. 323-368.

[41] Thiébaut E., Cabioch L., Dauvin J.-C., Retière C., Gentil F., Spatio-temporal persistence of the Abra alba-Pectinaria koreni muddy-fine sand community of the eastern Bay of Seine, J. Mar. Biol. Ass. UK 77 (1997) 1165-1185.

[42] Thiébaut E., Lagadeuc Y., Olivier F., Dauvin J.-C., Retière C., How do hydrodynamic factors affect the recruitment of marine invertebrates in a macrotidal area? The case study of Pectinaria koreni (Polychaeta) in the Bay of Seine (English Channel), Hydrobiologia 375/376 (1998) 165-176.

[43] Todd C.D., Larval supply and recruitment of benthic invertebrates: do larvae always disperse as much as we believe? Hydrobiologia 375/376 (1998) 1-21.

[44] Tremblay M.J., Loder J.W., Werner F.E., Naimie C.E., Page F.H., Sinclair M.M., Drift of sea scallop larvae Placopecten magellanicus on Georges Bank: a model study of the roles of mean advection, larval behavior and larval origin, Deep-Sea Res. II 41 (1994) 7-49.

[45] Underwood A.J., Fairweather P.G., Supply-side ecology and benthic marine assemblages, TREE 4 (1989) 16-20.

[46] Young E.F., Bigg G.R., Grant A., Walker P., Brown J., A modelling study of environmental influences on bivalve settlement in the Wash, England, Mar. Ecol. Prog. Ser. 172 (1998) 197-214. 